\title{
Guidelines for the laboratory diagnosis of genital herpes in eastern European countries
}

M Domeika (marius.domeika@medsci.uu.se) ${ }^{1}$, M Bashmakova² $^{2}$ A Savicheva ${ }^{2}$, N Kolomiec ${ }^{3}$, E Sokolovskiy ${ }^{4}$, A Hallén ${ }^{5}$, M Unemo ${ }^{6}$, R C Ballard 7 , Eastern European Network for Sexual and Reproductive Health (EE SRH Network) ${ }^{8}$

1. Department of Medical Sciences, Uppsala University, Uppsala, Sweden

2. Microbiology Laboratory, DO Ott Institute for Obstetrics and Gynaecology, St Petersburg, Russia

3. Microbiology Department, Belarus Medical Academy of Postgraduate Studies, Minsk, Belarus

4. Department of Dermatology and Venereology, Pavlov State Medical University, St Petersburg, Russia

5. Department of Dermatology and Venereology, Uppsala University Hospital, Uppsala, Sweden

6. Department of Laboratory Medicine, Clinical Microbiology, Örebro University Hospital, Örebro, Sweden

7. National Center for HIV, STD, and TB prevention, Centers for Disease Control and Prevention (CDC), Atlanta, United States

8. Members of the network are listed at the end of the article

Citation style for this article:

Domeika M, Bashmakova M, Savicheva A, Kolomiec N, Sokolovskiy E, Hallén A, Unemo M, Ballard RC, Eastern European Network for Sexual and Reproductive Health (EE SRH Network). Guidelines for the laboratory diagnosis of genital herpes in eastern European countries. Euro Surveill. 2010;15(44):pii=19703. Available online: http://www.eurosurveillance.org/ViewArticle.aspx?Articleld=19703

These guidelines aim to provide comprehensive information about sexually transmitted herpes simplex virus (HSV) infection and its laboratory diagnosis in eastern European countries. They are primarily intended for professionals testing specimens from patients at a sexual healthcare clinic but may also be helpful for community-based screening programmes. In particular, the guidelines recommend: (i) either viral culture or validated and approved nucleic acid amplification tests (NAATs) as the tests of choice for symptomatic patients, which should be promoted for laboratory confirmation of HSV infection; (ii) if culture or NAATs are not available, antigen detection - a direct immunofluorescence test or enzyme immunoassay from samples from symptomatic patients - could be employed, but HSV type determination is of importance; (iii) only type-specific serology should be used for detecting asymptomatic individuals, testing pregnant women at risk of acquiring HSV infection close to delivery, men who have sex with men and people who are HIV positive; (iv) widespread screening for HSV antibodies should be discouraged; and (v) any nonvalidated diagnostic tests should be validated against a recommended, approved gold standard.

\section{Introduction}

During the past 20 years, genital herpes has emerged as one of the most prevalent sexually transmitted infections (STIs). However, data on morbidity due to genital herpes infections in eastern European countries is scarce and their reliability doubtful owing to the lack of validation studies for the diagnostic tests used. The World Health Organization (WHO) has estimated a prevalence of herpes simplex virus type 2 (HSV-2) infection of 29 million cases in men and 12.3 million cases in women in eastern Europe and central Asia in 2003 [1]. The international classification of diseases caused by herpes virus (anogenital) [2] is presented in Table 1.
Human herpes simplex virus infections can be caused by HSV-1 or by HSV-2. In general, infections caused by HSV-1 manifest above the neck and are acquired as a result of close contact with infected persons, usually in childhood. In contrast, the lesions of infections caused by HSV-2 are usually located below the waist and are usually acquired as a result of sexual contact with infected persons later in life. Unfortunately, the differentiation of HSV-1 from HSV-2 based on anatomical site of infection is not absolute, since genital herpes may frequently be caused by HSV-1 as a result of orogenital sexual practices and vice versa. The lesions and natural history of the resulting illnesses are very similar. However, because HSV-2 is almost always associated with genital disease, whereas HSV-1 is associated with both oro-pharyngeal and genital disease, there is often considerable stigma associated with HSV-2 infection. Acquisition of HSV-1 usually results in lesions of the oro-pharynx and around the mouth and on the lips and chin. Occasionally the eyes are affected. Sexual transmission of HSV most often produces infection of the genital mucosa, genital skin (penile and labial) and the perigenital region. Virus from genital secretions

\section{TABLE 1}

International classification of diseases: anogenital herpes virus infection

\begin{tabular}{|c|l|}
\hline Classification code & Description \\
\hline A60 & $\begin{array}{l}\text { Anogenital herpesviral [herpes simplex] } \\
\text { infection }\end{array}$ \\
\hline A60.0 & $\begin{array}{l}\text { Herpesviral infection of genitalia and } \\
\text { urogenital tract }\end{array}$ \\
\hline A60.9 & $\begin{array}{l}\text { Herpesviral infection of perianal skin and } \\
\text { rectum }\end{array}$ \\
\hline & $\begin{array}{l}\text { Anogenital herpesviral infection, } \\
\text { unspecified }\end{array}$ \\
\hline
\end{tabular}

Source: [2]. 
can also infect other areas, including the eyes and oropharynx and rectal mucosa [3,4].

Primary herpetic infection, i.e. when an HSVseronegative person acquires HSV-1 or HSV-2, is usually the most severe manifestation of infection. Children may develop severe oro-pharyngitis following primary exposure to HSV-1. This episode resolves spontaneously, but recurrences may occur as a result of reactivation of the infection that has become latent but persists in the cervical ganglia. Similarly, if an individual has not been exposed to HSV-1 in childhood, he or she may develop severe genital lesions following sexual exposure to HSV-2 later in life. As with HSV-1 infections, primary HSV-2 infections resolve spontaneously but recurrences are likely to occur as a result of reactivation of latent infection that has been established in the sacral ganglia. In cases of initial, non-primary infection, i.e. when a person with antibodies to HSV-1 subsequently acquires HSV-2, the genital infection is less severe, but is also associated with recurrences. In most cases of genital herpes (80-90\%) the disease progresses subclinically, but may become symptomatic at any time $[5,6]$. The incubation period of both HSV-1 and HSV-2 is usually from two to 10 days (up to four weeks). Therefore, the first episode may indicate either recent or long-lasting infection [7].

Recurrent herpetic infection is associated with reactivation of the virus. The recurrences arise with different frequency: from once every few years to several times per month. The localisation of the primary and recurrent lesions usually coincides. Both oral and genital herpes are manifested by acute recurrences followed by varying periods of latency, when the virus remains in a non-multiplying episomal form in the nuclei of the neurons in the ganglia. Classically, each episode or recurrence is characterised by a patch of redness at the site of the recurrence, followed by a localised papular then vesicular rash. The vesicles contain a clear fluid that contains many thousands of infectious viral particles. These vesicles burst, forming shallow ulcers or erosions that eventually crust and heal spontaneously without leaving scars. These episodes usually last less than 10 days, but may be prolonged as a result of secondary bacterial infection or immunosuppression.

Genital and oral herpes are life-long infections. Neonatal herpes (including neonatal encephalitis) and increased risk for acquiring and shedding human immunodeficiency virus (HIV) are the most serious

TABLE 2

Main clinical symptoms, manifestations and complications of genital herpes infections

\begin{tabular}{|c|c|c|c|}
\hline Patients & Clinical symptoms & Clinical manifestations & Complications \\
\hline Females & $\begin{array}{l}\text { - Papular and/or vesicular rash on genitals or thighs } \\
\text { - Genital ulceration } \\
\text { - Dysuria } \\
\text { - Vaginal and/or cervical discharge } \\
\text { - Dyspareunia } \\
\text { - Inguinal discomfort }\end{array}$ & $\begin{array}{l}\text { - Papular and vesicular rash on } \\
\text { vulva, perineum, thighs } \\
\text { - Urethritis } \\
\text { - Vaginal discharge, Dysuria } \\
\text { - Dyspareunia } \\
\text { - Hyperaemia of the mucous } \\
\text { - } \text { membranes of vulva and vagina } \\
\text { - Cervicitis }\end{array}$ & \multirow{2}{*}{$\begin{array}{l}\text { - Viral meningitis } \\
\text { - Radiculomyelopathy with the } \\
\text { involvement of sacral nerves } \\
\text { - Extensive vesicular skin rash } \\
\text { - Increased risk for acquiring } \\
\text { and shedding human } \\
\text { immunodeficiency virus (HIV) }\end{array}$} \\
\hline Males & $\begin{array}{l}\text { - Papular and/or vesicular rash on genitals or thighs } \\
\text { - Genital ulceration } \\
\text { - Perineal pain } \\
\text { - Dysuria } \\
\text { - Inguinal discomfort }\end{array}$ & $\begin{array}{l}\text { - Papular and vesicular rash on } \\
\text { thighs, penis, perineum } \\
\text { - Urethral discharge } \\
\text { - Dysuria }\end{array}$ & \\
\hline $\begin{array}{l}\text { Newborns } \\
\text { (and/or } \\
\text { infants) }\end{array}$ & $\begin{array}{l}\text { - } \text { Vesicular skin rash } \\
\text { - Keratoconjunctivitis } \\
\text { - Mild pyrexia } \\
\text { - Lethargy } \\
\text { - Convulsions }\end{array}$ & $\begin{array}{l}\text { - Vesicular skin rash } \\
\text { - Keratoconjunctivitis } \\
\text { - Mild pyrexia } \\
\text { - Irritability } \\
\text { - Convulsions }\end{array}$ & $\begin{array}{l}\text { - Generalized skin rash } \\
\text { - Encephalitis } \\
\text { - Infant death }\end{array}$ \\
\hline
\end{tabular}

TABLE 3

Patient type and main indications for testing for genital herpes

\begin{tabular}{|c|c|}
\hline Patients & Indications for testing for genital herpes \\
\hline Males & $\begin{array}{l}\text { - Presence of vesicular and/or ulcerative lesions on penis, buttocks or perineum } \\
\text { - Symptoms of dysuria following treatment for gonorrhoea and/or nongonococcal urethritis } \\
\text { - History of recurrent vesicular and ulcerative genital skin lesions }\end{array}$ \\
\hline Females & $\begin{array}{l}\text { - Presence of vesicular and/or ulcerative lesions on the genitals, buttocks or thighs } \\
\text { - Presence of a mucous or purulent vaginal discharge } \\
\text { - History of recurrent vesicular and/or ulcerative genital skin lesions on the genitals, thighs, buttocks, perineum }\end{array}$ \\
\hline Newborns & $\begin{array}{l}\text { - Born to mothers who had genital herpes during pregnancy } \\
\text { - Vesicles, vesicular rash or crusts on skin }\end{array}$ \\
\hline Other & $\begin{array}{l}\text { - Had sexual contact with a proven case of genital herpes } \\
\text { - Being examined for other sexually transmitted infections } \\
\text { - Sex workers }\end{array}$ \\
\hline
\end{tabular}


consequences of genital herpes infection [8,9]. The main clinical symptoms, manifestations and complications of genital herpes infections are summarized in Table 2.

\section{Importance of laboratory diagnosis of genital herpes}

The clinical differentiation of genital HSV infection from other infectious and non-infectious aetiologies of genital ulceration is difficult and laboratory confirmation of the infection should always be sought $[5,9]$. Accordingly, exclusive reliance on clinical diagnosis could lead both to false positive and false negative diagnosis of the condition $[6,9]$. HSV is the most common cause of sexually acquired genital ulceration, however, the role of causative agents of other STIs, such as Treponema pallidum and Haemophilus ducreyi should not be forgotten. Occasionally HSV and T. pallidum can be recovered from the same lesion $[9,10]$. Non-infectious causes of genital ulceration, such as inflammatory bowel disease (Crohn disease), mucosal ulcerations associated with Behcet syndrome or fixed drug eruption, may also be confused with genital herpes [9]. The types of persons who are recommended to be tested for genital herpes infections are listed in Table 3.

\section{TABLE 4}

Recommendations for sample collection for the diagnosis of genital herpes infections

\begin{tabular}{|c|c|c|}
\hline $\begin{array}{l}\text { Specimen type or } \\
\text { collection site }\end{array}$ & Tools for sample collection & Collection method \\
\hline $\begin{array}{l}\text { Male skin or mucous } \\
\text { membrane lesions }\end{array}$ & $\begin{array}{l}\text { - Sterile needles } \\
\text { - Sterile cotton-wool or Dacron swab on } \\
\text { a wooden, plastic or aluminium shaft } \\
\text { - Microscope slides }\end{array}$ & $\begin{array}{l}\text { - Open the vesicles with a sterile needle. } \\
\text { - Collect the content of the vesicles with a swab and: } \\
\text { o apply to a microscope slide (for immunofluorescence staining) or } \\
\text { o introduce into transport media for viral culture or NAATs. }\end{array}$ \\
\hline Male urethra & $\begin{array}{l}\text { Sterile cotton-wool or Dacron swab on a } \\
\text { wooden, plastic or aluminium shaft }\end{array}$ & $\begin{array}{l}\text { - Clean the external urethral opening region with a swab moistened in } \\
\text { saline. } \\
\text { - Draw back the prepuce to avoid contamination when sampling. } \\
\text { Insert a cotton-wool or Dacron swab carefully into the external } \\
\text { urethral meatus (to a depth of } 0.5-2 \mathrm{~cm} \text { ) and collect urethral } \\
\text { exudates for testing. }\end{array}$ \\
\hline $\begin{array}{l}\text { Female skin or } \\
\text { mucous membrane } \\
\text { lesions }\end{array}$ & $\begin{array}{l}\text { - Gauze and cotton swabs } \\
\text { - Microscope slides }\end{array}$ & As for male skin or mucous membrane lesions. \\
\hline Female urethra & $\begin{array}{l}\text { - Sterile gauze swab (to remove excess } \\
\text { discharge) } \\
\text { - Sterile cotton-wool or Dacron swab on } \\
\text { an aluminium shaft }\end{array}$ & $\begin{array}{l}\text { - Clean the introitus using a sterile gauze swab. } \\
\text { - Carefully insert a cotton-wool or Dacron swab on an aluminium shaft } \\
\text { into the urethra (to a depth of } 0.5 \mathrm{~cm} \text { ) to collect exudates for testing. }\end{array}$ \\
\hline Cervix & $\begin{array}{l}\text { - Vaginal speculum } \\
\text { - Sterile gauze swab } \\
\text { - Sterile cotton-wool or Dacron swab on } \\
\text { a wooden or plastic shaft }\end{array}$ & $\begin{array}{l}\text { - Insert the vaginal speculum, which may be moistened in advance } \\
\text { with warm water and clean the cervical canal opening thoroughly } \\
\text { with a sterile gauze swab. } \\
\text { - Insert a cotton-wool or Dacron swab carefully into the cervical canal } \\
\text { (to a depth of } 2 \mathrm{~cm} \text { ) and collect the material from lesions. }\end{array}$ \\
\hline $\begin{array}{l}\text { Vagina } \\
\text { (of prepubertal girls) }\end{array}$ & $\begin{array}{l}\text { Cotton-wool or Dacron swab on an } \\
\text { aluminium shaft }\end{array}$ & $\begin{array}{l}\text { Insert a cotton-wool or Dacron swab on an aluminium shaft carefully } \\
\text { through the hymen into the vagina and collect the material from the } \\
\text { back wall of the vagina. }\end{array}$ \\
\hline Urine & Sterile container for urine & $\begin{array}{l}\text { Ask the patient to collect the first } 10-20 \mathrm{ml} \text { of voided urine (first catch). } \\
\text { Note: patients should avoid urinating for least two hours before } \\
\text { sampling. }\end{array}$ \\
\hline Conjunctiva & $\begin{array}{l}\text { - Sterile cotton-wool or Dacron swab on } \\
\text { wooden, plastic or aluminium shaft } \\
\text { - Kimura platinum conjunctival scraper } \\
\text { - Topical ophthalmic local anaesthetic }\end{array}$ & $\begin{array}{l}\text { - If there is purulent discharge, it must be removed with a cotton-wool } \\
\text { swab. } \\
\text { Move a swab over the conjunctiva of the inferior eyelid towards the } \\
\text { interior angle of the eye (use a thin swab on an aluminium shaft for } \\
\text { newborns). } \\
\text { The Kimura scraper is used to sample the bases of lesions (either } \\
\text { ulcers or the bases of burst vesicles). Before collecting the sample, } \\
\text { the spatula is sterilised by heating in a flame and allowed to cool. }\end{array}$ \\
\hline Rectum $^{a}$ & $\begin{array}{l}\text { - Rectal speculum or proctoscope } \\
\text { - Sterile cotton-wool or Dacron swab on } \\
\text { a wooden or plastic shaft }\end{array}$ & $\begin{array}{l}\text { - Rectal material is taken under direct vision, with the aid of a } \\
\text { proctoscope or rectal speculum. Use of a blind technique results in } \\
\text { considerable loss of sensitivity. } \\
\text { - Insert a swab on a wooden or plastic shaft to a depth of } 3 \mathrm{~cm} \text { and } \\
\text { collect the material from all rectal walls by circular motions for } 10 \\
\text { seconds. } \\
\text { Note: if faecal material is impacted, the swab should be discarded and } \\
\text { the sampling procedure repeated. }\end{array}$ \\
\hline
\end{tabular}

NAAT: nucleic acid amplification test.

a Material from the rectum is collected when the patient has had anal sexual contact, there are inflammatory changes, or if perianal skin or anal folds are thickened. 
The guidelines presented here represent the first attempt to introduce an evidence-based approach to the laboratory diagnosis of genital herpes infections in eastern Europe. It is recognised that national adjustments to these guidelines may be needed in some eastern European countries to meet local laws and health strategies and according to the availability of kits and reagents. They are a consensus document of the Eastern European Sexual and Reproductive Health (EE SRH) Network [11,12] and comprise one element of a series of guidelines aimed at optimising, standardising and providing guidance on quality assurance of laboratory testing for reproductive tract infections [13-16]. They are primarily intended for professionals testing specimens from patients at sexual healthcare clinics but may also be helpful for community-based screening programmes.

\section{Methods for laboratory diagnosis of genital herpes}

Laboratory confirmation of the clinical diagnosis is necessary for estimating the potential infectivity during episodes of lesions, identifying persons at risk of transmitting infection subclinically, selecting women at future risk of transmitting the infection to the neonate and confirming the clinical diagnosis in those for whom antiviral therapy for HIV infection should be prescribed [8].

Methods used for the diagnosis of HSV could be divided into direct detection of virus in material from lesions and serological diagnosis. Both virological detection and type-specific serological tests for HSV should be available in clinical settings that provide care for patients with STIs or those at risk for STIs.

The recommended sampling sites and type of sample and methods to be used for the diagnosis of genital herpes infection are presented in Table 4.

The recommendations for sample transportation for testing using microscopy, culture and NAATs are presented in Table 5.

The recommended sites and methods to be used for the diagnosis of genital herpes infection are presented in Table 6.

\section{Microscopy}

General

Microscopic examination of lesion materials using Romanovsky staining is used by a number of laboratories in Eastern Europe [17]. This method, however,

\section{TABLE 5}

Recommendations for sample transportation, by type of test

\begin{tabular}{|c|c|c|}
\hline Test method & Conditions & Comments \\
\hline Microscopy & $\begin{array}{l}\text { - If there is a need to save the material for more than } 24 \\
\text { hours, the smear should be fixed with } 96 \% \text { ethyl alcohol } \\
\text { for three minutes. } \\
\text { - Each smear on a microscope slide should be placed in the } \\
\text { transportation container and transported to the laboratory } \\
\text { accompanied by the relevant documentation including the } \\
\text { investigation method requested. }\end{array}$ & $\begin{array}{l}\text { - If the rules of sampling and conditions of } \\
\text { transportation of the biological material are not } \\
\text { followed (e.g. slides are broken, unmarked or } \\
\text { stuck together or there is no material on the slide), } \\
\text { microscopy should not be carried out. }\end{array}$ \\
\hline $\begin{array}{l}\text { Antigen detection } \\
\text { and nucleic acid } \\
\text { amplification tests } \\
\text { (NAATs) }\end{array}$ & $\begin{array}{l}\text { Transport medium is usually provided by the manufacturer of } \\
\text { the diagnostic system. } \\
\text { If the sample transportation procedure is not described in } \\
\text { the manufacturer's instructions or in-house test systems are } \\
\text { used, transportation is performed as follows. } \\
\text { - Clinical material placed, for instance, in transport medium } \\
\text { should be transported in the cold only (e.g. in a cool bag } \\
\left.\text { at } 6 \pm 2^{\circ} \mathrm{C}\right) \text {. } \\
\text { - Urine should be delivered to the laboratory within three } \\
\text { hours of collection, at ambient temperature. } \\
\text { Test tubes containing clinical material should be transported } \\
\text { to the laboratory accompanied by the relevant documentation } \\
\text { including the investigation method requested. }\end{array}$ & $\begin{array}{l}\text { - The material is delivered in special test tubes with } \\
\text { transport medium according to the manufacturer's } \\
\text { instructions for each test. } \\
\text { - Frozen }\left(-70^{\circ} \mathrm{C}\right) \text {, specimens to be tested using NAATs } \\
\text { may be kept for up to three months. However, } \\
\text { storage conditions must be in line with the } \\
\text { recommendations of the manufacturer of the NAAT. }\end{array}$ \\
\hline
\end{tabular}


as well as cytological examination using Tzanckand Papanicolaou smears, have been found to have low sensitivity and specificity, and therefore should not be relied upon for diagnosis $[5,9,18]$.

\section{Antigen detection}

General

Viral antigen from swab specimens can be detected using either direct immunofluorescence (DIF) or enzyme immunoassay (EIA). Commercial diagnostic tests produced in eastern European countries for the detection of herpes-specific virus antigen have not been validated against any international standard test; therefore the data presented below reflect characteristics of tests produced in western countries.

\section{Direct immunofluorescence}

DIF could be classified as a rapid diagnostic test allowing type differentiation of genital herpes viruses $[19,20]$. It can be valuable when testing high-prevalence populations [21], but when testing asymptomatic patients, the sensitivity may drop to less than $50 \%$ when compared with culture $[19,21]$. The disadvantages of DIF are that it is time consuming, labour intensive and, compared to NAATs, has a suboptimal sensitivity.

Antigen capture enzyme immunoassays

The sensitivity of commercially available ElAs, when compared with that of viral isolation, is greater than or equal to $95 \%$ and with specificities ranging from $62 \%$ to $100 \%$ for symptomatic patients [22-27]. The sensitivity of antigen capture ElAs may be higher than that of virus culture for typical presentations, but lower for cervical and urethral swabs $[22-24,27]$. Most commercially available assays, however, do not differentiate between serotypes.

\section{Viral isolation in cell culture \\ General}

Virus isolation in cell culture has been the cornerstone of HSV diagnosis over the past two decades in laboratories of western Europe $[28,29]$ and the United States [30]. Although HSV can be isolated from over $90 \%$ of vesicular or pustular lesions, the isolation rate from ulcerative lesions is only $70 \%$ and falls to $27 \%$ at the crusting stage [4]. Delayed transport of samples to the laboratory and lack of refrigeration during transportation substantially affect the outcome of the testing [31]. The characteristic cytopathic effect of HSV in tissue culture generally appears within 24-72 hours, but may take up to five days.

Virus isolation in tissue culture roller tubes is slow and labour intensive, but has the advantage of demonstrating active infection within a clinical lesion and also allows virus typing and antiviral sensitivity testing [32]. More rapid culture of HSV can be achieved by using shell vials [33] or multiwell plates [34] and centrifuging the specimen onto cell monolayers on coverslips. Commonly used cells include primary human fibroblasts and cell lines such as MRC- 5 , Vero cells, baby hamster kidney and rabbit kidney cells $[35,36]$.

Typing of HSV using cell culture can be performed directly on infected cell cultures using fluorescein isothiocyanate (FITC)- or immunoperoxidase-labelled type-specific monoclonal antibodies by DIF or by testing the cell supernatant by nucleic acid amplification tests (NAATs), with specifically designed primers.

\section{Storage of HSV isolates}

Isolates of HSV may be stored in $0.2 \mathrm{M}$ sucrose in 0.02 $M$ phosphate-buffered saline $\mathrm{pH} 7.2$ (2SP medium) at $-70^{\circ} \mathrm{C}$ or in liquid nitrogen.

\section{Nucleic acid amplification tests \\ General}

HSV detection using polymerase chain reaction (PCR) has been shown to be the test of choice in patients with genital herpes ulcers. The detection rates of the PCR assays were shown to be $11-71 \%$ superior to virus culture [30,31,37-39]. Furthermore, compared with traditional PCR, real-time PCR allows detection and typing of HSV in a single reaction tube, is faster (takes approximately two hours to perform), allows simplified conditions of performance and lowers the risk of

\section{TABLE 6}

Recommended sampling sites, type of sample and preferred diagnostic methods for genital herpes

\begin{tabular}{|l|l|}
\hline Sampling site or type of sample & Preferred diagnostic method \\
\hline Vesicular rash on skin and mucous membranes & Nucleic acid amplification test (NAAT) or antigen detection ${ }^{\mathrm{a}}$ \\
\hline Urethra (male) & NAAT or antigen detection \\
\hline Cervix/urethra (female) & NAAT or antigen detection \\
\hline Conjunctiva & NAAT or antigen detection \\
\hline Urine (men and women) & NAAT \\
\hline Vulva/vagina (prepubertal girls), vagina (women after hysterectomy) & NAAT \\
\hline Spinal cord fluid & NAAT \\
\hline Venous blood & Serological assays ${ }^{\text {}}$, e.g. enzyme immunoassays (EIAs) \\
\hline
\end{tabular}

a Viral culture is an additional method.

${ }^{b}$ For screening purposes, detecting newly acquired infections and diagnosis in persons who present without lesions or atypical lesions [31].

c For detection of type-specific herpes simplex virus type 2 (HSV-2) antibodies. 
cross-contamination [37]. Use of NAATs for diagnosis of HSV also allows less strict sample transportation conditions, compared with those required for diagnosis by culture.

As in western Europe and the United States, there are no comprehensively validated and approved commercial NAATs available for detection of HSV in many eastern European countries. However, some NAATs for HSV detection have been developed and are available in eastern Europe, but have not been validated against their internationally acknowledged analogues.

\section{Quality control}

In each DNA extraction and subsequent analysis, an internal positive control - allowing detection of amplification-inhibited samples and controlling the quality of sample preparation - and a negative control are necessary.

Certified and registered reference panels comprising coded control specimens should ideally be used for intra- and inter-laboratory quality control. The use of specimen panels is standard for test system operation. These act as indicators of sensitivity, specificity and reproducibility, which are independent of the test systems used.

\section{Serological tests}

Serological tests detect antibodies to HSV in blood, which are indicative of ongoing latent infection. Both type- and non-type-specific antibodies to HSV develop during the first several weeks after infection and persist indefinitely. However, directly after infection there is a 'window' in which testing for antibodies will give a negative result. Serodiagnosis is useful for documenting newly acquired infections and for diagnosis in persons who present without lesions or with atypical lesions. Testing for HSV type-specific antibodies can also be used to diagnose HSV-2 infection in asymptomatic individuals $[31,40]$, and other persons with undiagnosed HSV-2 infection. Whether genital herpes is caused by HSV-1 or HSV-2 influences prognosis and counselling. Up to $50 \%$ of first-episode cases of genital herpes are caused by HSV-1 [41], but recurrences and subclinical viral shedding are much less frequent for genital HSV-1 infection than genital HSV-2 infection $[42,43]$.

\section{Validation of diagnostic tests}

General criteria for the validation of diagnostic tests have been published by the TDR diagnostics evaluation expert panel (TDR is a Special Programme for Research and Training in Tropical Diseases, sponsored by the United Nations Children's Fund (UNICEF), the United Nations Development Programme (UNDP), the World Bank and WHO [44]. The criteria are demanding and beyond the capacity of most individual groups. However, the minimum requirements for the validation of a new or modified test have also been published [45].

\section{Summary}

Older, classical tests can display cross-reactivity between HSV-1 and HSV-2 and even with varicellazoster virus. During the past 20 years, a number of type-specific tests have been developed, the sensitivity and specificity of which have been evaluated to be approximately $97 \%$ and $98 \%$, respectively [46]. Although the benefits of the serological assays (such as type-specific EISAs) include the possibility of automation and therefore simultaneous processing of a large number of samples at relatively low cost, they have a number of disadvantages that considerably limit their use in the diagnosis of genital herpes. Although the detection of HSV-specific IgM is theoretically useful to detect recent herpes infection in the absence of an IgG response, approximately a third of patients with recurrent genital herpes caused by HSV-2 have IgM responses; thus detection of IgM is a poor indicator of recent infection. Unfortunately, serological tests alone cannot inform the aetiology of a presenting genital lesion with any degree of certainty.

\section{Recommendations}

Where viral culture facilities exist, they should be maintained in order to detect the causative virus directly from skin and mucous membrane lesions. Where culture is not available, consideration should be given to the introduction of a NAAT for HSV. If NAATs are not available, antigen detection, namely DIF or EIA, could be employed, if high performance of those tests can be assured. HSV type determination is important to inform counselling and prognosis. Type-specific serology should be used for detecting asymptomatic individuals, testing pregnant women at risk of acquiring HSV infection close to delivery, men who have sex with men, and people who are HIV positive. Widespread screening for HSV antibodies should be discouraged. It is recommended that any non-validated diagnostic tests should be validated against a recommended, approved gold standard test.

Members of the Eastern European Network for Sexual and Reproductive Health Network

Karen Babayan, Edgar Manukian (Armenia); Rashad Ismailov (Azerbaijan); Iryna Shimanskaya, Oleg Pankratov, Natalia Kolomiec, Oxana Kudina (Belarus); Krasimira Chudomirova (Bulgaria); Tanja Brilene (Estonia); George Galdava, Oleg Kvivlidze (Georgia); Judith Deak (Hungary); Gulsum Askarova, Aliya Utegenova (Kazakhstan); Dilara Uusupova, Evgenia Al-Kilani (Kyrgyzstan); Andris Rubins (Latvia); Vesta Kucinskiene (Lithuania); Vera Kisina, Elena Shipitsyna, Tatjana Krasnoselskich, Alexandr Guschin (Russia); Abbos Kasimov, Olim Kasimov (Tajikistan); Gennadij Mavrov, Natalya Kochetova, Glib Bondarenko (Ukraine); Sharof Ibragimov, Olga Izvekova, Talat Nabiev (Uzbekistan).

\section{Acknowledgements}

These guidelines were written on behalf of the STI Diagnostic Group of the EE SRH Network, which is supported by grants from the East Europe Committee of the Swedish Health Care Community, Swedish International Development Cooperation Agency (SIDA). The project coordinator is Marius Domeika. 
1. Looker KJ, Garnett PG, Schmid GP. An estimate of the global prevalence and incidence of herpes simplex virus type 2 infection. Bull World Health Organ. 2008;86(10):805-12.

2. World Health Organization (WHO). Infections with a predominantly sexual mode of transmission (A50-A64). In: International statistical classification of diseases and related health problems, 10th revision, version for 2007. Geneva: WHO; 2007. Available from: http://www.who.int/ classifications/apps/icd/icd1oonline/

3. Corey L, Adams HG, Brown ZA, Holmes KK. Genital herpes simplex virus infections: clinical manifestations, course, and complications. Ann Intern Med. 1983;98(6):958-72.

4. Corey L, Spear PG. Infections with herpes simplex viruses (1). N Engl J Med. 1986;314(11):686-91.

5. Corey L, Holmes KK. Genital herpes simplex virus infections: current concepts in diagnosis, therapy, and prevention. Ann Intern Med. 1983;98(6):973-83.

6. Langenberg AG, Corey L, Ashley RL, Leong WP, Straus SE. A prospective study of new infections with herpes simplex virus type 1 and type 2 . Chiron HSV Vaccine Study Group. N Engl J Med. 1999;341(19):1432-8.

7. Wald A, Zeh J, Selke S, Warren T, Ryncarz AJ, Ashley R, et al. Reactivation of genital herpes simplex virus type 2 infection in asymptomatic seropositive persons. N Engl J Med. 2000;342:844-50.

8. Wald A, Link K. Risk of human immunodeficiency virus infection in herpes simplex virus type 2-seropositive persons: a meta-analysis. J Infect Dis. 2002;185(1):45-52.

9. Corey L, Wald A. Genital herpes. In: KK Holmes, PF Sparling, WE Stamm, P Piot, JW Wasserheit, L Corey, et al., editors. Sexually transmitted diseases, 4 th ed. New York: McGraw Hill; 2008. p. 399-437.

10. Chapel TA, Jeffries CD, Brown WJ. Simultaneous infection with Treponema pallidum and herpes simplex virus. Cutis. 1979;24(2):191-2.

11. Domeika M, Savicheva A, Sokolovskiy E, Ballard R, Unemo M Guidelines for laboratory diagnosis of Neisseria gonorrhoeae infections in Eastern European countries--results of an international collaboration. Euro Surveill. 2007;12 (49). pii: 3326. Available from: http://www.eurosurveillance.org/ ViewArticle.aspx?Articleld $=3326$

12. Domeika M, Savicheva A, Sokolovskiy E, Ballard R, Unemo M; Eastern European Network for Sexual and Reproductive Health (EE SRH Network). Quality enhancements and quality assurance of laboratory diagnosis of sexually transmitted infections in Eastern Europe. Int J STD AIDS. 2009;20(5):365-7

13. Savicheva A, Sokolovsky E, Frigo N, Priputnevich T, Brilene T, Deak J, et al. Guidelines for laboratory diagnosis of Neisseria gonorrhoeae in East-European countries. Part 1: gonorrhoea, sampling, and microscopy for diagnosis. Acta Medica Lituanica. 2007;4:65-74.

14. Savicheva A, Sokolovsky E, Frigo N, Priputnevich T, Brilene T, Deak J, et al. Guidelines for laboratory diagnosis of Neisseria gonorrhoeae in East-European countries. Part 2: culture, nonculture methods, determination of antibiotic resistance, and quality assurance. Acta Medica Lituanica. 2007;4:123-34.

15. Sokolovskiy E, Frigo N, Rotanov S, Savicheva A, Dolia O, Kitajeva N, et al. Guidelines for the laboratory diagnosis of syphilis in East European countries. J Eur Acad Dermatol Venereol. 2009;23(6):623-32.

16. Domeika M, Savicheva A, Sokolovskiy E, Frigo N, Brilene T, Hallén A, et al. Guidelines for the laboratory diagnosis of Chlamydia trachomatis infections in East European countries. J Eur Acad Dermatol Venereol. 2009;23(12):1353-63.

17. Domeika M, Hallén A, editors. Chlamydia trachomatis infections in Eastern Europe. Kaunas: KATA Studio; 2000.

18. Koutsky LA, Stevens CE, Holmes KK, Ashley RL, Kiviat NB, Critchlow CW, et al. Underdiagnosis of genital herpes by current clinical and viral-isolation procedures. N Engl J Med. 1992;326(23):1533-9.

19. Moseley RC, Corey L, Benjamin D, Winter C, Remington ML. Comparison of viral isolation, direct immunofluorescence, and indirect immunoperoxidase techniques for detection of genital herpes simplex virus infection. J Clin Microbiol.1981;13(5):913-8.

20. Langford MP, Villarreal AL, Stanton GJ. Antibody and interferon act synergistically to inhibit enterovirus, adenovirus, and herpes simplex virus infection. Infect Immun. 1983;41(1):214-8.

21. Lafferty WE, Krofft S, Remington M, Giddings R, Winter C, Cent $A$, et al. Diagnosis of herpes simplex virus by direct immunofluorescence and viral isolation from samples of external genital lesions in a high-prevalence population. J Clin Microbiol.1987;25(2):323-6.
22. Warford AL, Levy RA, Rekrut KA. Evaluation of a commercial enzyme-linked immunosorbent assay for detection of herpes simplex virus antigen. J Clin Microbiol. 1984;20(3):490-3.

23. Slomka MJ, Emery L, Munday PE, Moulsdale M, Brown DW. A comparison of PCR with virus isolation and direct antigen detection for diagnosis and typing of genital herpes. J Med Virol.1998;55(2):177-83.

24. Koenig M, Reynolds KS, Aldous W, Hickman M. Comparison of Light-Cycler PCR, enzyme immunoassay, and tissue culture for detection of herpes simplex virus. Diagn Microbiol Infect. Dis. 2001;40(3):107-10.

25. Burrows J, Nitsche A, Bayly B, Walker E, Higgins G, Kok T. Detection and subtyping of Herpes simplex virus in clinical samples by LightCycler PCR, enzyme immunoassay and cell culture. BMC Microbiol. 2002;2:12.

26. Kok T, Mickan L, Schepetiuk S. Rapid detection, cultureamplification and typing of herpes simplex viruses by enzyme immunoassay in clinical samples. Clin Diagn Virol. 1998;10(1):67-74.

27. Gonik B, Seibel M, Berkowitz A, Woodin MB, Mills K. Comparison of two enzyme-linked immunosorbent assays for detection of herpes simplex virus antigen. J Clin Microbiol. 1991;29(3):436-8.

28. Cone RW, Swenson PD, Hobson AC, Remington M, Corey L. Herpes simplex virus detection from genital lesions: a comparative study using antigen detection (HerpChek) and culture. J ClinMicrobiol. 1993;31(7):1774-6.

29. Scoular A, Kinghorn G. British Co-operative Clinical Group national survey on diagnostic issues surrounding genital herpes. MSSVD Special Interest Group on Genital Herpes and the British Co-operative Clinical Group. Sex Transm Infect. 1999;75(6):403-5.

30. Geretti AM, Brown DW. National survey of diagnostic services for genital herpes. Sex Transm Infect. 2005;81(4):316-7.

31. Centers for Disease Control and Prevention, Workowski KA, Berman SM. Sexually transmitted diseases treatment guidelines. MMWR Recomm Rep. 2006;55(RR-11):1-94.

32. Wald A. Testing for genital herpes: how, who, and why. Curr Clin Top Infect Dis. 2002;22:166-80.

33. Scoular A. Using the evidence base on genital herpes: optimising the use of diagnostic tests and information provision. Sex Transm Infect. 2002;78(3):160-5.

34. Salmon VC, Turner RB, Speranza MJ, Overall JC Jr.. Rapid detection of herpes simplex virus in clinical specimens by centrifugation and immunoperoxidase staining. J Clin Microbiol. 1986;23(4):683-6.

35. Ziegler T, Waris M, Rautiainen M, Arstila P. Herpes simplex virus detection by macroscopic reading after overnight incubation and immunoperoxidase staining. J Clin Microbiol. 1988;26(10):2013-7.

36. Fayram L, Aarnaes SL, Peterson EM, de la Maza LM. Evaluation of five cell types for the isolation of Herpes simplex virus. Diagn Microbiol Infect Dis. 1986;5(2):127-33.

37. Ramaswamy M, McDonald C, Smith M, Thomas D, Maxwell $S$, Tenant-Flowers $M$, et al. Diagnosis of genital herpes by real time PCR in routine clinical practice. Sex Transm Infect. 2004;80(5):406-10.

38. Geretti AM. Genital herpes. Sex Transm Infect. 2006;82(Suppl 4):iv31-4.

39. Scoular A, Gillespie G, Carman WF. Polymerase chain reaction for diagnosis of genital herpes in a genitourinary medicine clinic. Sex Transm Infect. 2002;78(1):21-5.

40. Ashley RL. Genital herpes. Type-specific antibodies for diagnosis and management. Dermatol Clin. 1998;16(4):789-93.

41. Roberts CM, Pfister JR, Spear SJ. Increasing proportion of herpes simplex virus type 1 as a cause of genital herpes infection in college students. Sex Transm Dis. 2003;30(10):797-800.

42. Benedetti J, Corey L, Ashley R. Recurrence rates in genital herpes after symptomatic first-episode infection. Ann Intern Med. 1994;121(11):847-54.

43. Engelberg R, Carrell D, Krantz E, Corey L, Wald A. Natural history of genital herpes simplex virus type 1 infection. Sex Transm Dis. 2003;30(2):174-7.

44. Banoo S, Bell D, Bossuyt P, Herring A, Mabey D, Poole F, et al. Evaluation of diagnostic tests for infectious diseases: general principles. Nat Rev Microbiol. 2006;4(12 Suppl):S20-32.

45. Peeling RW, Smith PG, Bossuyt PM. A guide for diagnostic evaluations. Nat Rev Microbiol. 2006;4(12 Suppl):S2-6.

46. Ashley RL. Sorting out the new HSV type specific antibody tests. Sex Transm Infect. 2001;77(4):232-7. 